Article

\title{
The FuGas 2.3 Framework for Atmosphere-Ocean Coupling: Comparing Algorithms for the Estimation of Solubilities and Gas Fluxes
}

\author{
Vasco M. N. C. S. Vieira ${ }^{1, *}$, Pavel Jurus ${ }^{2,3}$, Emanuela Clementi ${ }^{4}$ and Marcos Mateus $^{1}$ (ib \\ 1 MARETEC-Marine Environment and Technology, Instituto Superior Técnico, Universidade de Lisboa, \\ Av Rovisco Pais, 1049-001 Lisboa, Portugal; marcos.mateus@tecnico.ulisboa.pt \\ 2 DataCastor, U Svobodarny 1063/6, 19000 Praha 9 Prague, Czech Republic; pavel.jurus@gmail.com \\ 3 Institute of Computer Science, Czech Academy of Sciences, 11720 Prague, Czech Republic \\ 4 Istituto Nazionale di Geofisica e Vulcanologia, INGV, 40128 Bologna, Italy; emanuela.clementi@ingv.it \\ * Correspondence: vasco.vieira@tecnico.ulisboa.pt
}

Received: 8 May 2018; Accepted: 2 August 2018; Published: 9 August 2018

\begin{abstract}
Accurate estimates of the atmosphere-ocean fluxes of greenhouse gases and dimethyl sulphide (DMS) have great importance in climate change models. A significant part of these fluxes occur at the coastal ocean which, although much smaller than the open ocean, have more heterogeneous conditions. Hence, Earth System Modelling (ESM) requires representing the oceans at finer resolutions which, in turn, requires better descriptions of the chemical, physical and biological processes. The standard formulations for the solubilities and gas transfer velocities across air-water surfaces are 36 and 24 years old, and new alternatives have emerged. We have developed a framework combining the related geophysical processes and choosing from alternative formulations with different degrees of complexity. The framework was tested with fine resolution data from the European coastal ocean. Although the benchmark and alternative solubility formulations generally agreed well, their minor divergences yielded differences of up to $5.8 \%$ for $\mathrm{CH}_{4}$ dissolved at the ocean surface. The transfer velocities differ strongly (often more than $100 \%$ ), a consequence of the benchmark empirical wind-based formulation disregarding significant factors that were included in the alternatives. We conclude that ESM requires more comprehensive simulations of atmosphere-ocean interactions, and that further calibration and validation is needed for the formulations to be able to reproduce it. We propose this framework as a basis to update with formulations for processes specific to the air-water boundary, such as the presence of surfactants, rain, the hydration reaction or biological activity.
\end{abstract}

Keywords: solubility; transfer velocity; Henry constant

\section{Introduction}

The dynamics of the atmosphere-ocean gas exchanges plays a central role in the Earth's climate, with the ocean acting simultaneously as a sink and source of greenhouse gases and a source of dimethyl sulfide (DMS) to the atmosphere. However, and despite the observed seasonal, inter-annual and regional variability [1-3], the open ocean is generally assumed to act as a sink for atmospheric $\mathrm{CO}_{2}$. In the sub-polar regions, for instance, the solubility pump retrieves large amounts of greenhouse gases from the atmosphere, which are then advected to the deep ocean [1,2]. On the other hand, at the surface of coastal waters the balances and fluxes of $\mathrm{CO}_{2}, \mathrm{CH}_{4}, \mathrm{~N}_{2} \mathrm{O}$ and DMS are very heterogenic, mostly due to factors like upwelling, plankton productivity, and land-originated loads of both natural and anthropogenic cause. Consequently, besides DMS $[3,4]$ the coastal ocean can be, at least seasonally, also a source of $\mathrm{CO}_{2}[1,2,5-11], \mathrm{CH}_{4}[2,10,12]$, and $\mathrm{N}_{2} \mathrm{O}[2,10,13-15]$ to the atmosphere. 
Thus, the uncertainty on the atmosphere-coastal ocean exchange of $\mathrm{CO}_{2}$ begs the question about the overall budget of the global ocean $[1,3,6,16]$.

The atmosphere-ocean flux of gases is controlled by the unbalance between the air and water concentrations (the latter mediated by solubility), and by the transfer velocity [17-22]. The solubility of gases at the surface can be estimated by algorithms with different physical and chemical backgrounds [20-27]. The transfer velocity depends on numerous processes occurring at the sea surface [17-22,28]. However, large-scale simulations of relevant processes for the air-water gas exchange at the coastal ocean and their inherent variability poses serious difficulties for Earth System Models (ESM) and marine biogeochemical models. Constraints related to computational demands explain why such models usually simulate the biosphere at decadal or centennial time scales with daily intervals and spatial resolutions of hundreds to $1000 \mathrm{~km}$. Such are the cases of ESM applications by the Intergovernmental Panel on Climate Change (IPCC), Max Planck Institute (MPI) or Centro Euro-Mediterraneo sui Cambiamenti Climatici (CMCC). Hand in hand with the low resolution for space and time, the atmosphere-ocean gas fluxes are estimated with simple algorithms that disregard the complexity of processes recently unveiled at the coastal ocean. Hence, the standard in current ESM is the parameterization by Wanninkhof [29], relying on wind speed at $10 \mathrm{~m}$ elevation under atmospherically neutral conditions $\left(\mathrm{u}_{10 \mathrm{~N}}\right)$ as the sole driver of transfer velocity. ESM relies on the dominance of strong winds over the global ocean to support the coarse resolution of geophysical process. Contradicting this rationale, Wanninkhof et al. [19] demonstrated that the largest amount of atmosphere-ocean $\mathrm{CO}_{2}$ exchange occurs under low-to-moderate winds. Concomitantly, there emerged empirical formulae best fitting low wind data collected from estuaries. Such are the formulations proposed by Carini et al. [30] or Raymond and Cole [31], accounting only for $\mathbf{u}_{10}$, or by Borges et al. [32], adding current drag with the bottom. Meanwhile, new evidence emerged for the effects of the sea surface cool-skin and warm-layer [33-38], atmospheric stability [39,40], wave-breaking [41-50], water surface renewal [28,51-57], surfactants [28,58-60] and rain [61-64], just to mention a few examples from an extensive list of published works. In addition to their single influence, these factors also interact. For instance, while surfactants increase surface tension, although decreasing the water surface renewal and micro-scale wave breaking $[28,65]$, there is no report of them affecting whitecap from breaking waves. Surfactants are expected to be more relevant on the coastal ocean due to their supply from land and their effect being more pronounced under low-moderate winds $[60,66]$.

There are many simplistic formulae estimating the gas transfer velocity from the few factors that were determinant for the specific set of data used in their calibration. However, modelling the coastal oceans with fine resolution requires algorithms providing adequate representation of the many processes involved. Developing such an algorithm demands a modular framework able to be updated with the best formulation for each of the mediator processes, and to test and compare different algorithms as well as different degrees of complexity. Hence, we developed the FuGas (Flux of Gases) framework [21,22], currently in its version 2.3. This simulation tool includes 67 alternative formulations to account for factors such as solubility, wind or current-mediated turbulence, atmospheric stability, sea-surface roughness, breaking waves, air and water viscosities, temperature and salinity. This framework is also able to automatically select simpler algorithms in particular locations with insufficient data for more comprehensive solutions. The framework can be used to estimate the air-water fluxes of any atmospheric gas by selecting the respective constants. In this work we rely on the FuGas 2.3 to compare estimates of $\mathrm{CO}_{2}$ transfer velocities obtained by simpler empirical formulations with some more comprehensive alternatives focusing on the sea state. We tested the effect of wave-state with field data from the Baltic Sea. Also, we coupled the Weather Research and Forecasting (WRF) atmospheric model to the WaveWatch III (WW3)-NEMO oceanographic model using simulated data from the European coastal ocean. These new tests are particularly relevant given recent findings that the sea state in fetch-limited locations (as is the coastal ocean) has an influence on the transfer velocity, by contrast with that from the fetch-unlimited open ocean $[50,55,57]$. 


\section{Methods}

Air-water gas fluxes result from the interaction of two factors: (i) the imbalance between the gas concentrations in the air and in the water sets the strength and direction of the flux; and (ii) the resistance the medium does for being crossed by the flow [17-22]. Most formulae estimate the flux from $\mathrm{F}=\mathrm{k}_{\mathrm{w}} \cdot \mathrm{k}_{\mathrm{H}} \mathrm{cp} \cdot \Delta \mathrm{p}_{\text {gas }}$. The $\mathrm{k}_{\mathrm{H}} \mathrm{cp}$ is the Henry's constant for gas solubility in its $\mathrm{C}_{\mathrm{w}} / \mathrm{p}_{\mathrm{a}}$ form, where $\mathrm{p}_{\mathrm{a}}$ is the gas partial pressure in the air and $\mathrm{C}_{\mathrm{w}}$ its concentration in the water. The $\Delta \mathrm{p}_{\text {gas }}$ is the difference between the partial pressures of the gas in the air $\left(\mathrm{p}_{\mathrm{a}}\right)$ and in the water $\left(\mathrm{p}_{\mathrm{w}}\right)$ i.e., $\Delta \mathrm{p}_{\text {gas }}=\mathrm{p}_{\mathrm{w}}-\mathrm{p}_{\mathrm{a}}$. In this form, a positive flux represents uptake by the atmosphere while a negative flux represents uptake by the ocean. The $\mathrm{p}_{\mathrm{a}}$ must be corrected for the partial pressure of water vapour considering saturation over the sea surface: $\mathrm{p}_{\text {moist }}=\left(1-\mathrm{p}_{\mathrm{H} 2 \mathrm{O}} / \mathrm{P}\right) \mathrm{p}_{\mathrm{dry}}$. This conversion is detailed in Section 2.1 below. The $\mathrm{k}_{\mathrm{w}}$ is the transfer velocity of gases across the sub-millimetre thick water surface layer. For moderately soluble gases the airside resistance is not negligible. In these cases, the double layer model [17-22] estimates the flux taking into consideration both the water-side and air-side surface layers and thus, $F=K_{w}\left(C_{w}-C_{a} / k_{H}\right)=K_{a}\left(C_{w} \cdot k_{H}-C_{a}\right)$. The $C_{a}$ and $C_{w}$ are the concentrations of the gas in air and water and the $\mathrm{k}_{\mathrm{H}}$ is Henry's constant in its equivalent dimensionless quantity $\left(C_{a} / C_{w}\right)$. The transfer velocity is estimated from both layers as $K_{w}=\left(1 / k_{w}+1 /\left(k_{H} \cdot k_{a}\right)\right)^{-1}$ or its equivalent $K_{a}=\left(k_{H} / k_{w}+1 / k_{a}\right)^{-1}$. Supplementary Table S1 provides a list of the variables and constants presented in this article. Other variables and constants used in subsidiary calculations are not included. The link to software and data is provided in the Supplementary Materials.

\subsection{Solubility}

Sarmiento and Gruber [2] compiled the algorithm for the $\mathrm{k}_{\mathrm{H}} \mathrm{cp}$ dependence on temperature and salinity provided by Weiss [23] and Weiss and Price [24]. We converted it to its corresponding dimensionless $\mathrm{k}_{\mathrm{H}}$ preserving the constants required to estimate Bunsen's solubility coefficient $(\beta)$ (Equation (1) or Equation (2)). Solubility coefficients were estimated from the Virial expansion (Equation (3)), where $B$ was $\beta$ or $\beta / V_{m}$, depending on which gas it was applied to (Table 3.2.2 in Sarmiento and Gruber [2]). Our software automatically detected the gas from the $a_{i}$ coefficient. When $B=\beta$ the $k_{H}$ was estimated from Equation (1), whereas when $B=\beta / V_{m}$ the $k_{H}$ was estimated from Equation (2). This formulation accounted for fugacity (f) of non-ideal gases (Equation (4)) and corrected the gas partial pressure for moisture effects from $\mathrm{p}_{\text {moist }}=\left(1-\mathrm{p}_{\mathrm{H} 2 \mathrm{O}} / \mathrm{P}\right) \mathrm{p}_{\mathrm{dry}}$ considering water vapour saturation over the sea-surface (Equation (5)). Calculations required the air pressure $(\mathrm{P})$, water temperature $\left(T_{w}\right)$, salinity $(S)$, ideal gas law constant $(R)$, molar volume of the specific gas $\left(V_{m}\right)$ and the molar volume of ideal gases $\left(\mathrm{V}_{\text {ideal }}\right)$.

$$
\begin{gathered}
\mathrm{k}_{\mathrm{H}}=\left(1-\frac{\mathrm{p}_{\mathrm{H}_{2} \mathrm{O}}}{\mathrm{P}}\right) \frac{101.325 \mathrm{~V}_{\mathrm{m}}}{\mathrm{RT}_{\mathrm{w}} \beta \mathrm{f}} \\
\mathrm{k}_{\mathrm{H}}=\frac{101.325}{\mathrm{RT}_{\mathrm{w}} \beta \mathrm{f}} \\
\log (\mathrm{B})=\mathrm{a}_{1}+\mathrm{a}_{2} \frac{100}{\mathrm{~T}_{\mathrm{w}}}+\mathrm{a}_{3} \log \frac{\mathrm{T}_{\mathrm{w}}}{100}+\mathrm{a}_{4}\left(\frac{\mathrm{T}_{\mathrm{w}}}{100}\right)^{2}+\mathrm{S} \cdot\left(\mathrm{b}_{1}+\mathrm{b}_{2} \frac{\mathrm{T}_{\mathrm{w}}}{100}+\mathrm{b}_{3}\left(\frac{\mathrm{T}_{\mathrm{w}}}{100}\right)^{2}\right) \\
\mathrm{f}=\exp \left(\frac{101.325 \mathrm{P}\left(\mathrm{V}_{\mathrm{m}}-\mathrm{V}_{\text {ideal }}\right)}{\mathrm{RT}_{\mathrm{w}}}\right) \\
\log \frac{\mathrm{p}_{\mathrm{H}_{2} \mathrm{O}}}{\mathrm{P}}=24.4543-67.4509\left(\frac{100}{\mathrm{~T}_{\mathrm{w}}}\right)-4.8489 \ln \left(\frac{\mathrm{T}_{\mathrm{w}}}{100}\right)-0.000544 \mathrm{~S}
\end{gathered}
$$

Johnson [20] developed an algorithm from another approach that corrected for the effects of temperature and salinity on the molecular and thermodynamic properties of the water, its solutes and the specified gas, based on a ideal gas behaviour. His formulae were developed from the compilation by Sander [27] (available on the web since 1999) of the $k_{H} c p$ for nearly all gases in the atmosphere at 
$25{ }^{\circ} \mathrm{C}(298.15 \mathrm{~K})$ and 0 ppt. Then, Equation (6) converted the $\mathrm{k}_{\mathrm{H}} \mathrm{cp}$ to $\mathrm{k}_{\mathrm{H}}$ at a given temperature and $0 \mathrm{ppt}$ salinity. The term $-\Delta_{\text {soln }} \mathrm{H} / \mathrm{R}$ reflected the temperature dependence of solubility, having a value of 2400 for $\mathrm{CO}_{2}, 1700$ for $\mathrm{CH}_{4}$ and 2600 for $\mathrm{N}_{2} \mathrm{O}$. The correction to a given salinity (Equation (7)) relied on the empirical Setschenow constants $\left(\mathrm{K}_{\mathrm{S}}=\theta \cdot \log \mathrm{V}_{\mathrm{b}}\right)$ reporting the effect of electrolytes salting-out gases proportionally to their liquid molar volume at boiling point $\left(\mathrm{V}_{\mathrm{b}}\right)$. The $\mathrm{V}_{\mathrm{b}}$ was estimated using the additive Schroeder method, whereas $\theta$ was estimated from Equation (8) using a provisional $\mathrm{k}_{\mathrm{H} \#}=0.0409 / \mathrm{k}_{\mathrm{H}} c \mathrm{p}$.

$$
\begin{gathered}
\mathrm{k}_{\mathrm{H}, 0}=\frac{12.1866}{\mathrm{P} \cdot \mathrm{T}_{\mathrm{W}} \cdot \mathrm{k}_{\mathrm{H}, \mathrm{cp}} \cdot \mathrm{e}^{\frac{-\Delta_{\mathrm{Soln}} \mathrm{H}}{\mathrm{R}}\left(1 / \mathrm{T}_{\mathrm{w}}-1 / 298.15\right)}} \\
\mathrm{k}_{\mathrm{H}}=\mathrm{k}_{\mathrm{H}, 0} \cdot 10^{\mathrm{K}_{\mathrm{s}} \mathrm{S}} \\
\theta=7.33532 \cdot 10^{-4}+3.39615 * 10^{-5} \cdot \log \left(\mathrm{k}_{\mathrm{H} \#}\right) \\
-2.40888 \cdot 10^{-6} \cdot \log \left(\mathrm{k}_{\mathrm{H} \#)^{2}}\right. \\
+1.57114 \cdot 10^{-7} \cdot \log \left(\mathrm{k}_{\mathrm{H} \#}\right)^{3}
\end{gathered}
$$

\subsection{Transfer Velocity}

The simpler transfer velocity formulations rely on the wind velocity $10 \mathrm{~m}$ above the sea surface $\left(\mathrm{u}_{10}\right)$ under atmospherically neutral conditions. Among then, the formulation by Wanninkhof [29] (henceforth also referred to as 'Wan92') became the standard used in ESM and satellite data processing (Equation $(9 \mathrm{a}, \mathrm{b}))$. It includes the Schmidt number of the water $\left(\mathrm{Sc}_{\mathrm{W}}\right)$, related to viscosity, raised to an exponent sensitive to the assumed model of surface renewal. For sparingly soluble gases or for $\mathrm{CO}_{2}$ in alkaline waters, and under low winds, the transfer velocity is enhanced by the hydration reaction $\left(b_{T}\right)$, which is sensitive to temperature.

$$
\begin{gathered}
\mathrm{k}_{\mathrm{w}}=\left(\mathrm{b}_{\mathrm{T}}+0.31 \cdot \mathrm{u}_{10}^{2}\right)\left(\frac{\mathrm{Sc}_{\mathrm{w}}}{660}\right)^{-0.5} \\
\mathrm{~b}_{\mathrm{T}}=2.5 \cdot\left(0.5246+0.0162 \mathrm{~T}_{\mathrm{w}}+0.000499 \mathrm{~T}_{\mathrm{w}}^{2}\right)
\end{gathered}
$$

Other simple empirical formulations based only on $\mathrm{u}_{10}[30,31]$, or also accounting for bottom-generated turbulence [32], used data collected in estuaries under low wind conditions. However, modelling the coastal ocean at finer resolutions requires an enhanced representation of the multitude of processes involved. Hence, we updated the framework by Vieira et al. [21], with the $\mathrm{k}_{\mathrm{w}}$ being decomposed into its shear produced turbulence $\left(\mathrm{k}_{\mathrm{wind}}+\mathrm{k}_{\text {current }}\right)$ and bubbles from whitecapping ( $\mathrm{k}_{\text {bublle }}$ ) forcings [32,41,42,44]. $\mathrm{Sc}_{\mathrm{w}}$ was determined from temperature and salinity following Johnson [20]:

$$
\mathrm{k}_{\mathrm{w}}=\left(\mathrm{b}_{\mathrm{T}}+\mathrm{k}_{\text {bubble }}+\mathrm{k}_{\text {wind }}+\mathrm{k}_{\text {current }}\right) \cdot\left(600 / \mathrm{Sc}_{\mathrm{w}}\right)^{0.5}
$$

The formulation by Zhao et al. [43], merged $k_{\text {wind }}$ within the $k_{\text {bubble }}$ (Equation (11a)), being this term dependent on the wave breaking parameter $\left(R_{B}\right.$ given by Equation $\left.(11 b)\right)$. The $u *$ was the friction velocity i.e., the velocity of wind dragging on the sea surface, and $f_{p}$ the peak angular frequency of the wind-waves (in rad. ${ }^{-1}$ ). We estimated the kinematic viscosity of air $\left(v_{a}\right)$ from Johnson [20].

$$
\begin{gathered}
\mathrm{k}_{\text {bubble }}+\mathrm{k}_{\text {wind }}=0.1315 \cdot \mathrm{R}_{\mathrm{B}}^{0.6322} \\
\mathrm{R}_{\mathrm{B}}=\frac{\mathrm{u}_{*}^{2}}{2 \pi \mathrm{f}_{\mathrm{p}} v_{\mathrm{a}}}
\end{gathered}
$$

Later, Zhao and Xie [47] developed a more elaborate algorithm. While the output was still given by Equation (11a), $R_{b}$ was now estimated from Equation (12a). $R_{H U}$ was a turbulent Reynolds number (Equation (12b)) accounting for the sea state by using the significant wave height $\left(\mathrm{H}_{\mathrm{s}}\right)$. The wave age 
( $\beta$ ) was estimated from Equation (12c) using the gravitational acceleration constant (g). While Zhao and Xie [47] tested their algorithm with the drag coefficient $\left(C_{D}\right)$ estimated from several empirical formulations, here we estimated $C_{D}$ from its definition $\left(C_{D}=u *{ }^{2} / u_{10}{ }^{2}\right)$. This was only possible because $\mathrm{u} *$ was estimated from $\mathrm{u}_{10}$ using the wind log-linear profile as presented below.

$$
\begin{gathered}
\mathrm{R}_{\mathrm{B}}=4.79 \cdot \mathrm{C}_{\mathrm{D}} \cdot \beta^{-2 / 3} \mathrm{R}_{\mathrm{HU}} \\
\mathrm{R}_{\mathrm{HU}}=\frac{\mathrm{u}_{10} \cdot \mathrm{H}_{\mathrm{s}}}{v_{\mathrm{a}}} \\
\beta=2.56\left(\frac{\mathrm{g} \cdot \mathrm{H}_{\mathrm{s}}}{\mathrm{u}_{10}^{2}}\right)^{3 / 5}
\end{gathered}
$$

The formulation by Woolf [44] split the estimation of $k_{\text {wind }}$ and $k_{\text {bubble. }}$. The $k_{\text {wind }}$, taken from Jähne et al. [66], related to the transfer mediated by the turbulence generated by wind drag (Equation (13)). The $\mathrm{k}_{\text {bubble }}=850 \mathrm{~W}$ related to the transfer mediated by the bubbles generated by breaking waves. The whitecap cover was estimated from $\mathrm{W}=4.02 \cdot 10^{-7} \mathrm{R}_{\mathrm{H}}{ }^{0.96}$, and the dimensionless form of the Reynolds number for wind waves estimated from $\mathrm{R}_{\mathrm{H}}=\mathrm{u} * \mathrm{H}_{\mathrm{s}} / v_{\mathrm{a}}$.

$$
\mathrm{k}_{\mathrm{wind}}=1.57 \cdot 10^{-4} \cdot \mathrm{u}_{*}
$$

The friction velocity $\left(\mathrm{u}_{*}\right)$ was estimated from the wind log-linear profile (WLLP: Equation (14)) accounting for wind speed at height $\mathrm{z}\left(\mathrm{u}_{\mathrm{z}}\right)$, atmospheric stability of the surface boundary layer (through $\psi_{\mathrm{m}}$ ) and sea-surface roughness (through the roughness length $\mathrm{z}_{0}$ ). Here, $\mathrm{k}$ is von Kármàn's constant. Historically, the WLLP originated from Monin-Obukhov similarity theory [67].

$$
\mathrm{u}_{*}=\frac{\mathrm{u}_{\mathrm{z}} \cdot \mathrm{k}}{\ln (\mathrm{z})-\ln \left(\mathrm{z}_{0}\right)+\psi_{\mathrm{m}}\left(\mathrm{z}, \mathrm{z}_{0}, \mathrm{~L}\right)}
$$

Roughness length $\left(\mathrm{z}_{0}\right)$ is the theoretical minimal height (most often sub-millimetric) at which wind speed averages zero. It is dependent on surface roughness and often used as its index. It is more difficult to determine over water than over land as there is a strong bidirectional interaction between wind and sea surface roughness. Taylor and Yelland [68] proposed a dimensionless $\mathrm{z}_{0}$ dependency from the wave field, increasing with the wave slope (Equation (15)) as estimated from the significant wave height $\left(\mathrm{H}_{\mathrm{s}}\right)$ and peak wave period $\left(\mathrm{L}_{\mathrm{p}}\right)$. Due to the bidirectional nature of the $\mathrm{z}_{0}$ and $\mathrm{u} *$ relation, we also tested an iterative solution (iWLP) where Equation (15) was used as a first guess for the $z_{0}$ and Equation (14) for its subsequent $u_{*}$. A second iteration re-estimated $z_{0}$ from the COARE 3.0 [69] adaptation of the Taylor and Yelland [68] formulation, whereby a term for smooth flow was added (Equation (16)), and $\mathrm{u} *$ was estimated back again from Equation (14). Applying four iterations were enough for an excellent convergence of the full data array. The coefficients proposed by Taylor and Yelland [68] yielded implausibly high $\mathrm{z}_{0}$ when applied to steep young waves originated by a storm over the central Mediterranean Sea and by strong Mistral blowing off-shore of southern France, corresponding to $2.85 \%$ of our observations. These extreme $\mathrm{z}_{0}$ led to absurdly high $\mathrm{u} *$ and $\mathrm{k}_{\mathrm{w}}$, and thus we imposed a maximum roughness length of $0.01 \mathrm{~m}$. This value roughly matches the maximum expected from the application of alternative formulations for the estimation of $\mathrm{z}_{0}$ from the wave field [70-74].

$$
\begin{gathered}
\frac{\mathrm{z}_{0}}{\mathrm{H}_{\mathrm{s}}}=1200 \cdot\left(\frac{\mathrm{H}_{\mathrm{s}}}{\mathrm{L}_{\mathrm{p}}}\right)^{4.5} \\
\mathrm{z}_{0}=1200 \cdot \mathrm{H}_{\mathrm{s}}\left(\frac{\mathrm{H}_{\mathrm{s}}}{\mathrm{L}_{\mathrm{p}}}\right)^{4.5}+\frac{0.11 v_{\mathrm{a}}}{\mathrm{u}_{*}}
\end{gathered}
$$

Atmospheric stability characterized the tendency of the surface boundary layer (SBL) to be well mixed (unstable SBL with $\psi_{\mathrm{m}}<0$ ) or stratified (stable SBL with $\psi_{\mathrm{m}}>0$ ). The $\psi_{\mathrm{m}}$ was inferred 
from the bulk Richardson number $\left(\mathrm{Ri}_{\mathrm{b}}\right)$, weighting the air vertical heat gradient and kinetic energy (Equation (17)). Hence, it required the air virtual potential temperature $\left(T_{v}\right)$ and wind speed at two heights $(\mathrm{z})$ within the SBL. Alternatively, the $\mathrm{Ri}_{\mathrm{b}}$ was directly estimated from the air potential temperature $\left(\mathrm{T}_{\mathrm{p}}\right)$ i.e., replacing $\mathrm{T}_{\mathrm{v}}$ and, thus, neglecting humidity [75].

$$
\mathrm{Ri}_{\mathrm{b}}=\frac{\mathrm{g} \Delta \mathrm{T}_{\mathrm{v}} \Delta \mathrm{z}}{\mathrm{T}_{\mathrm{v}} \mathrm{u}_{\mathrm{z}}^{2}}
$$

$T_{V}$ was estimated from $T_{p}$ and humidity, following Equation (18) [39] or Equation (19) [67]. Each equation requires different humidity inputs, namely the observed specific humidity (q), relative humidity $\left(\mathrm{h}_{\mathrm{r}}\right)$, liquid water mixing ratio $\left(\mathrm{r}_{\mathrm{L}}\right)$ and water vapour mixing ratio at saturation $\left(\mathrm{r}_{\text {sat }}\right)$ :

$$
\begin{gathered}
\mathrm{T}_{\mathrm{v}}=\mathrm{T}_{\mathrm{p}}(1+0.61 \mathrm{q}) \\
\mathrm{T}_{\mathrm{v}}=\mathrm{T}_{\mathrm{p}}\left(1+0.61 \mathrm{q} \cdot \mathrm{r}_{\mathrm{sat}} \cdot \mathrm{h}_{\mathrm{r}}+\mathrm{r}_{\mathrm{L}}\right)
\end{gathered}
$$

$T_{p}$ and $r_{\text {sat }}$ were estimated from the air temperature $\left(T_{k a}\right)$ and pressure $(P)$ [67]:

$$
\begin{gathered}
\mathrm{T}_{\mathrm{p}}=\mathrm{T}_{\mathrm{k}, \mathrm{a}}\left(\frac{1000}{1013.25 \mathrm{P}}\right)^{0.284} \\
\mathrm{r}_{\mathrm{sat}}=\frac{0.622 \mathrm{e}_{\mathrm{sat}}}{101.32501 \mathrm{P}-\mathrm{e}_{\mathrm{sat}}} \\
\ln \left(\mathrm{e}_{\mathrm{sat}}\right)=\ln 0.61078+\frac{17.2694 \mathrm{~T}_{\mathrm{a}}}{\mathrm{T}_{\mathrm{k}, \mathrm{a}}-35.86}
\end{gathered}
$$

At surface height $\mathrm{z} \approx 0 \mathrm{~m}$, the wind velocity must be set to the theoretical $\mathrm{u}_{0}=0$, temperature given by the SST $[34,39,69]$ with rectification for cool-skin and warm-layer effects [34-38], and humidity set to the saturation level at $\mathrm{P}_{0}$ and $\mathrm{T}_{0}$ using $\mathrm{q}=\mathrm{r}_{\text {sat }} /\left(1+\mathrm{r}_{\text {sat }}\right)$ [69].The $\mathrm{Ri}_{\mathrm{b}}$ was used to estimate the length L from the Monin-Obukhov's similarity theory, a discontinuous exponential function tending to $\pm \infty$ when $\mathrm{Ri}_{\mathrm{b}}$ tends to \pm 0 and tending to \pm 0 when $\mathrm{Ri}_{\mathrm{b}}$ tends to $\pm \infty$. $\mathrm{Ri}_{\mathrm{b}}$ and $\mathrm{L}$ were used to estimate $\psi_{\mathrm{m}}$ following Stull [67] or Lee [75] algorithms. The transfer velocity of moderately soluble gases, besides taking into consideration the molecular crossing of the water-side surface layer, should also take into consideration the molecular crossing of the air-side surface layer [17-22]. We compared values from a single layer model and two-layer "thin film" model [17], the later estimating the air-side transfer velocity $\left(k_{a}\right)$ from the COARE formulation as in Equation (23) [46]. $C_{D}$ is the drag coefficient and $\mathrm{Sc}_{\mathrm{a}}$ the Schmidt number of air, which were determined for a given temperature and salinity following Johnson [20].

$$
\mathrm{k}_{\mathrm{a}}=\frac{\mathrm{u}_{*}}{13.3 \cdot \mathrm{Sc}_{\mathrm{a}}^{1 / 2}+\mathrm{CD}^{1 / 2}-5+\frac{\log \left(\mathrm{Sc}_{\mathrm{a}}\right)}{2 \mathrm{~K}}}
$$

\subsection{Validation with Field Data}

The algorithms presented in Section 2.2 were applied to observed oceanographic and atmospheric variables (Level 2 data). These are derived geophysical variables at the same resolution and location as the instrument source data (Level 1). For these estimates we used the FuGas 2.2 single processing ensemble. The forecasted $\mathrm{CO}_{2}$ transfer velocities were compared to those inferred from $\mathrm{k}_{\mathrm{w}}=\mathrm{F} / \Delta \mathrm{p}_{\text {gas }}$, where $\mathrm{F}$ were the $\mathrm{CO}_{2}$ vertical fluxes measured by eddy-covariance, and the $\Delta \mathrm{p}_{\text {gas }}$ were the differences between measured atmospheric and oceanic $\mathrm{CO}_{2}$ concentrations. The field sampling occurred from 22 May 2014 to 26 May 2014 using the atmospheric tower at Östergarnsholm in the Baltic Sea $\left(57^{\circ} 27^{\prime} \mathrm{N}, 18^{\circ} 59^{\prime} \mathrm{E}\right)$, the Submersible Autonomous Moored Instrument $\left(\mathrm{SAMI}-\mathrm{CO}_{2}\right) 1 \mathrm{~km}$ away and the Directional Waverider (DWR) $3.5 \mathrm{~km}$ away, both south-eastward of the tower [9,76]. The atmospheric measurements were done at $12 \mathrm{~m}$ heights. The DWR measured temperatures at $0.5 \mathrm{~m}$ depth, taken as 
representative for the sea-surface. Salinity was obtained from the Asko mooring data provided by the Baltic In-Situ Near-Real-Time Observations available in Copernicus Marine catalogue.

The eddy-covariance $(\mathrm{E}-\mathrm{C})$ measurements were subject to quality control. We only used the fluxes for which the wind direction set the SAMI-CO $\mathrm{CO}_{2}$ and DWR in the footprint of the atmospheric tower $\left(100^{\circ}<\right.$ wind direction $\left.<160^{\circ}\right)$. We rejected periods for which there were abrupt changes in wind speed or direction as these represented strong violations of the required homogeneous conditions [77]. An extra filter was applied to remove measurements in which wave age denoted large dominance of swell conditions $(\beta>2)$, since they have been identified as biasing measurements of transfer velocity $[47,48]$. When the ratio is $>1$ the waves move faster than the wind, indicating the presence of swell $[47,48]$. Using only the observations passing the quality control check, the air-water $\mathrm{CO}_{2}$ fluxes measured by eddy-covariance were smoothed over $30 \mathrm{~min}$ bins and corrected according to the Webb-Pearman-Leuning (WPL) method [78].

\subsection{Application within Geoscientific Models}

The transfer velocities of $\mathrm{CO}_{2}, \mathrm{CH}_{4}$ and $\mathrm{N}_{2} \mathrm{O}$ were estimated from atmospheric and oceanographic re-analysed (Level 4) data retrieved for the European shores (Mediterranean and North Atlantic to the tip of Scotland) from the 24 May 2014 at $06 \mathrm{~h}$ to the 27 May 2014 at $00 \mathrm{~h}$. All variables were interpolated to the same $0.09^{\circ}$ grid (roughly $11 \mathrm{~km}$ at Europe's latitudes) and $1 \mathrm{~h}$ time steps. This resulted in a data set with 17 variables $\times 41,776$ locations $\times 66$ time instances. For a faster processing of the $\approx 2 \mathrm{~Gb}$ of Level 4 data, we used the multiple processing ensemble of the FuGas 2.3.

The atmospheric variables were retrieved from the standard operational application of the WRF by Meteodata.cz, with model output at $9 \mathrm{~km}$ horizontal and $1 \mathrm{~h}$ time resolutions. The vertical thickness of the WRF layers varied with space and time. The atmospheric variables where retrieved from the two lowest levels within the SBL. These levels refer to the horizontal layers in the atmospheric model, and are not to be mistaken by the data processing level. Over the ocean, these levels occurred roughly at $0 \mathrm{~m}$ and $12 \mathrm{~m}$ heights. The second level provided the wind velocity, temperature, pressure and humidity at $\mathrm{z}$ meters above sea surface. At surface height $\mathrm{z} \approx 0 \mathrm{~m}$, the wind velocity was set to the theoretical $\mathrm{u}_{0}=0$, and temperature was given by the SST without rectification for cool-skin and warm-layer effects due to the lack of some required variables. Yet, these effects tend to compensate each other $[34,37,38]$. Air pressure was given by the WRF at the lower level $(\approx 0 \mathrm{~m})$ and humidity was set to the saturation level using $\mathrm{P}_{0}$ and $\mathrm{T}_{0}$.

The sea surface temperature (SST, here also named $\mathrm{T}_{\mathrm{w}}$ ) and salinity (S) were estimated by the NEMO modelling system provided in the MyOcean catalogue with $1 / 12^{\circ}$ and 1 day resolutions. The WW3 wave field data for the Mediterranean Sea was supplied by the Istituto Nazionale di Geofisica e Vulcanologia (INGV) using the WW3-NEMO modelling system at $0.0625^{\circ}$ and $1 \mathrm{~h}$ resolutions [79], and for the North Atlantic by Windguru at roughly $0.5^{\circ}$ and $3 \mathrm{~h}$ resolutions. The variables included significant wave height $\left(\mathrm{H}_{\mathrm{s}}\right)$ and peak frequency $\left(\mathrm{f}_{\mathrm{p}}\right)$ for wind sea i.e., disregarding swell. A few aspects did not correspond to the ideal data format for atmosphere-ocean coupling and required further calculations: (i) The peak wave length $\left(\mathrm{L}_{\mathrm{p}}\right)$ was estimated from the peak frequency assuming the deep-water approximation: $\mathrm{L}_{\mathrm{p}}=2 \pi \mathrm{g} / \mathrm{f}_{\mathrm{p}}{ }^{2}$; (ii) the Windguru data did not provide a wind sea component where (and when) the wind was too low. For these missing cases, the lowest $\mathrm{H}_{\mathrm{s}}$ were attributed and $\mathrm{L}_{\mathrm{p}}$ was simulated everywhere else; and (iii) the Windguru and the INGV data overlapped along the Iberian shores, in which case the INGV was given a 2:1 weight over the Windguru data.

SST and S were used to estimate how the solubility algorithms could lead to different estimates of greenhouse gases dissolved below the ocean surface. First, the solubility was converted to the $\mathrm{C}_{\mathrm{w}} / \mathrm{C}_{\mathrm{a}}$ form corresponding to $1 / \mathrm{k}_{\mathrm{H}}$. Then, the differences in solubility between the two algorithms, as estimated from Equation (24), led to the differences in the estimates of greenhouse gases dissolved per cubic meter immediately below the ocean surface (Equation (25)).

$$
\Delta \mathrm{s}=\frac{1}{\mathrm{k}_{\mathrm{H}}[\operatorname{Sar} 13]}-\frac{1}{\mathrm{k}_{\mathrm{H}}[\mathrm{Joh} 10]}=\frac{\mathrm{C}_{\mathrm{w}}[\operatorname{Sar} 13]-\mathrm{C}_{\mathrm{w}}[\text { Joh10 }]}{\mathrm{C}_{\mathrm{a}}}
$$




$$
\Delta \mathrm{g} \times \mathrm{m}^{-3}=\frac{\Delta \mathrm{s} \cdot \rho_{\mathrm{gas}} \cdot \mathrm{P} \cdot 101325 \cdot \mathrm{M}_{\mathrm{gas}}}{10^{6} \mathrm{RT}}
$$

For these calculations, time variability was disregarded assuming the average $\Delta$ s over the $66 \mathrm{~h}$ time interval. The $\Delta \mathrm{C}_{\mathrm{W}}$ was converted to mass units using the molar weights of the specific gas $\left(\mathrm{M}_{\text {gas }}\right)$, respectively 44.01 for $\mathrm{CO}_{2}, 16.043$ for $\mathrm{CH}_{4}$ and 44.013 for $\mathrm{N}_{2} \mathrm{O}$. The $\mathrm{C}_{\mathrm{a}}$ was estimated from the atmospheric pressure ( $\mathrm{P}$ in atm) and the partial pressure ( $\left.\rho_{\text {gas }}\right)$ of $\mathrm{CO}_{2}, \mathrm{CH}_{4}$ or $\mathrm{N}_{2} \mathrm{O}, 390 \mathrm{ppm}$, $1.75 \mathrm{ppm}$ and $0.325 \mathrm{ppm}$ respectively [80], assuming that they were approximately uniform all over the atmospheric surface boundary layer (SBL). The $\rho_{\text {gas }}$ was divided by $10^{6}$ to re-scale from ppm to dimensionless. Using the ideal gas law, we divided by $R$ and $T_{a}$ (assumed $T_{a}=T_{w}$ at the sea-surface), and multiplied by 101325 to convert atm back to Pascal.

\section{Results and Discussion}

\subsection{Solubility Estimates}

The solubility formulae were compared for the range of environmental conditions commonly found in nature: water temperature $\left(\mathrm{T}_{\mathrm{W}}\right)$ ranged from $-2{ }^{\circ} \mathrm{C}$ to $30^{\circ} \mathrm{C}$ at $1{ }^{\circ} \mathrm{C}$ intervals and a salinity (S) ranged from 0 ppt to $38 \mathrm{ppt}$ at $1 \mathrm{ppt}$ intervals. In general, both formulations estimated similar solubilities despite their distinct chemistry backgrounds, as demonstrated by their ratio $\mathrm{k}_{\mathrm{H}[20]} / \mathrm{k}_{\mathrm{H}[2]}$ close to 1 (Figure 1a-c). Nevertheless, differences from $10 \%$ to $-5 \%$ for $\mathrm{CO}_{2}, 11 \%$ to $5 \%$ for $\mathrm{CH}_{4}$, and $7 \%$ to $-5 \%$ for $\mathrm{N}_{2} \mathrm{O}$ were observed in freshwaters. Determining which formulation provides more accurate estimates of greenhouse gas (GHG) solubilities in freshwater is fundamental for Earth System Modelling, because rivers and freshwater reservoirs are important sources of GHG to the atmosphere, even if only seasonably [7-14,16]. In marine waters, our simulations found differences of up to $12 \%$ for $\mathrm{CO}_{2}, 9 \%$ for $\mathrm{CH}_{4}$ and $7 \%$ for $\mathrm{N}_{2} \mathrm{O}$, suggesting that for marine waters is also important to determine which formulation provides more accurate estimates of GHG solubilities. Afterwards, both formulae were applied to the conditions observed at the European coastal ocean during the experiment (the Level 4 SST, S and P). The surface water temperature changed significantly and there were large fresh water inflows from the Black Sea and the Baltic Sea (Figure 2 and Supplementary Video S1). Solubility estimates were averaged over a $66 \mathrm{~h}$ time interval and compared at each location by their ratio (Figure $1 \mathrm{~d}-\mathrm{f}$ ). Higher divergences reached $+4.5 \%$ for $\mathrm{CO}_{2}$ solubility in cooler marine waters, $+5.65 \%$ for $\mathrm{CH}_{4}$ solubility in warmer saltier waters, and $-2.1 \%$ for $\mathrm{N}_{2} \mathrm{O}$ solubility in brackish waters. Hence, the algorithms diverge by as much as $0.045 \mathrm{~mol} \cdot \mathrm{mol}^{-1}$ of $\mathrm{CO}_{2}, 0.0015 \mathrm{~mol} \cdot \mathrm{mol}^{-1}$ of $\mathrm{CH}_{4}$ and $0.012 \mathrm{~mol} \cdot \mathrm{mol}^{-1}$ of $\mathrm{N}_{2} \mathrm{O}$ (i.e., mol of gas in the ocean surface per mol of gas in the atmosphere) in some of the most sensitive situations for Earth System Modelling and satellite data processing, namely: (i) the cooler marine sub-polar waters where the solubility pump traps greenhouse gases and carries them to the deep ocean [2], and (ii) the warmer waters at the coastal ocean and seas, which have regularly been observed having greenhouse gases and DMS dissolved in concentrations highly unbalanced with those of the atmosphere [2-16].

The discrepancies between solubilities estimated by either algorithm led to differences in the estimates of GHG dissolved per cubic meter immediately below the ocean surface (Figure 3). The major differences occurred in the regions with the cooler waters, the warmer waters and the brackish waters. These biases in the estimated total amount of greenhouse gases for the European coastal ocean's surface during late May 2014, may be an indicator of higher global biases. Hence, similar comparisons with data from other locations and/or periods are required. Performing these comparisons is facilitated the by the FuGas framework. 

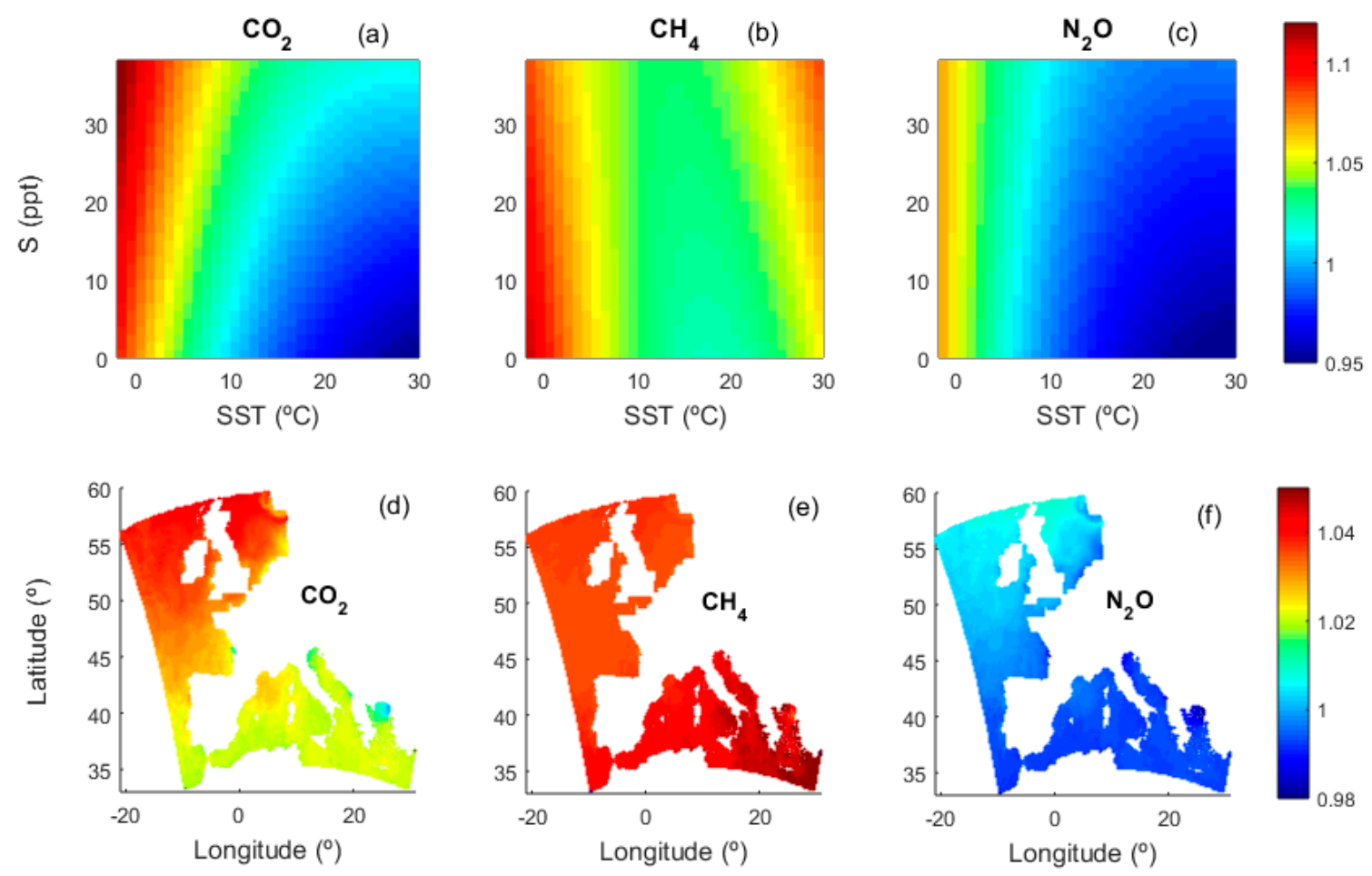

Figure 1. Match-mismatch between estimated solubilities of greenhouse gases. Colour scale is quotient between $\mathrm{k}_{\mathrm{H}}$ estimated from Johnson [20] and from Sarmiento and Gruber [2]. Solubilities tested for the range of values observable at the Earth's surface $(\mathbf{a}-\mathbf{c})$ and at the European coastal ocean from the 24 May 2014 at $06 \mathrm{~h}$ to the 27 May 2014 at $00 \mathrm{~h}(\mathbf{d}-\mathbf{f})$ with each pixel corresponding to a square sided $11 \mathrm{~km}$ and averaged over the $66 \mathrm{~h}$ survey period.
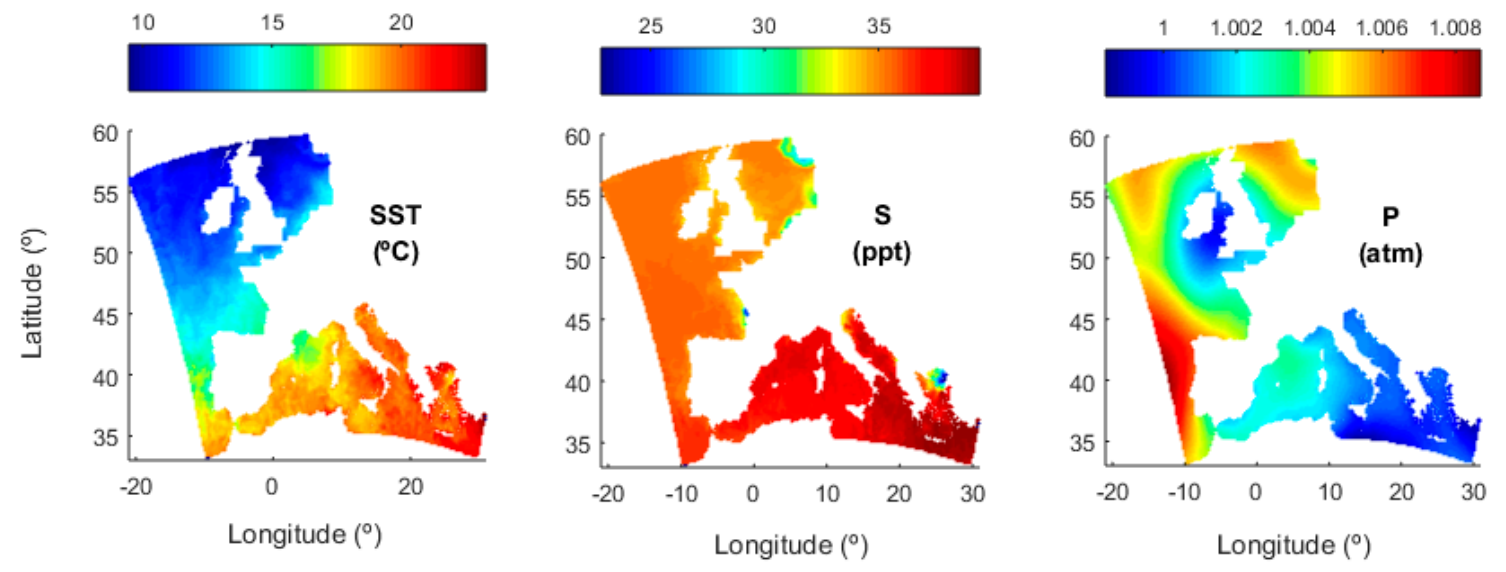

Figure 2. Sea surface temperature (SST), salinity (S) and air pressure (P) at the European coastal ocean from the 24 May 2014 at $06 \mathrm{~h}$ to the 27 May 2014 at $00 \mathrm{~h}$. Each pixel corresponds to a square sided $11 \mathrm{~km}$ and averaged over the $66 \mathrm{~h}$ survey period. 

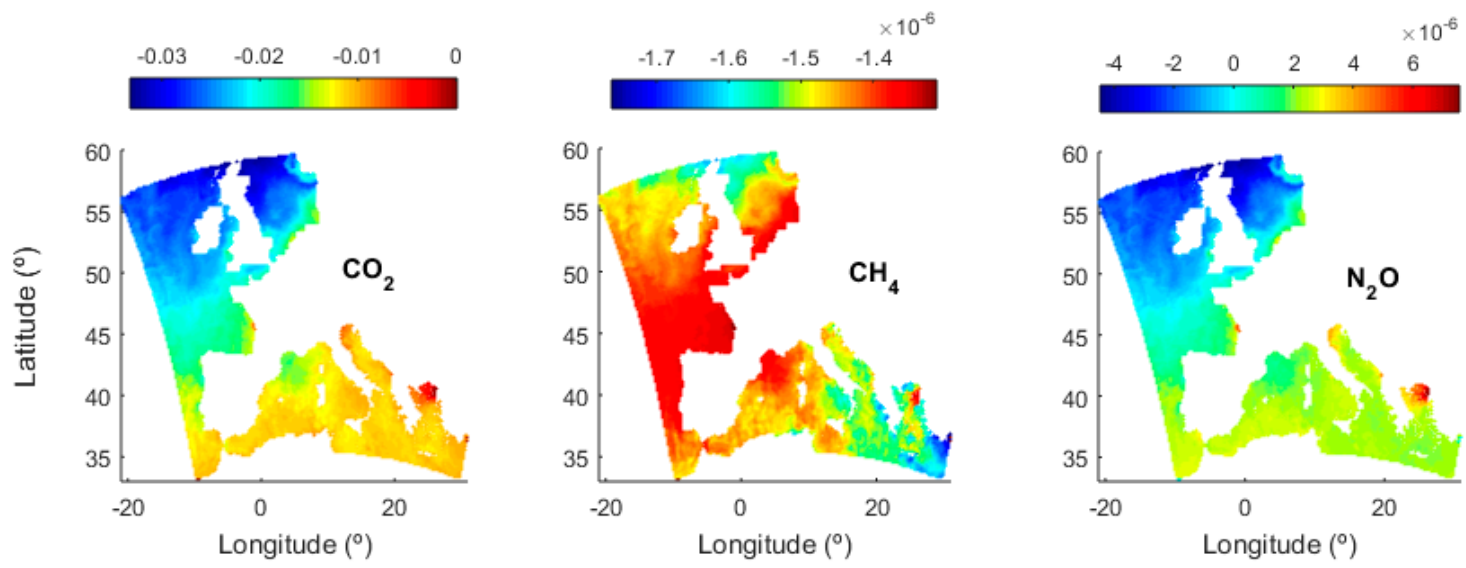

Figure 3. Bias in the gas mass estimated by each algorithm $\left(\Delta \mathrm{g} \cdot \mathrm{m}^{-3}\right)$. Comparing algorithms by Johnson [20] to compilation by Sarmiento and Gruber [2]. Colourscale: $\Delta \mathrm{g} \mathrm{m}^{-3}$.

\subsection{Transfer Velocity Estimates from Field Data}

The transfer velocity $\left(\mathrm{k}_{\mathrm{w}}\right)$ scaled with $\mathrm{u}_{10}(\mathrm{r}=0.91)$ and with the inverse of the wave age $(r=-0.88)$ i.e., the younger the waves, the larger the $k_{w}$ (Figure 4$)$. This fits the general theory that under low-moderate wind speeds, the $\mathrm{k}_{\mathrm{w}}$ is set by surface renewal and micro-scale wave breaking (i.e., by $k_{\text {wind }}$ ), increasing with steeper younger waves [28,51,65], and only under higher wind speeds is $\mathrm{k}_{\mathrm{w}}$ set by bubbles from breaking waves (i.e., $\mathrm{k}_{\text {bubble }}$ ) [41-50]. The preponderance of surface renewal and micro-scale wave breaking at the coastal ocean turn it more susceptible to additional factors driving $\mathrm{k}_{\mathrm{w}}$. As an example, under the low-moderate wind speeds often verified at the coastal ocean, the hydration reaction enhances $\mathrm{k}_{\mathrm{w}}$ [19] and surfactants attenuate surface renewal $[28,58,59,65,66]$.
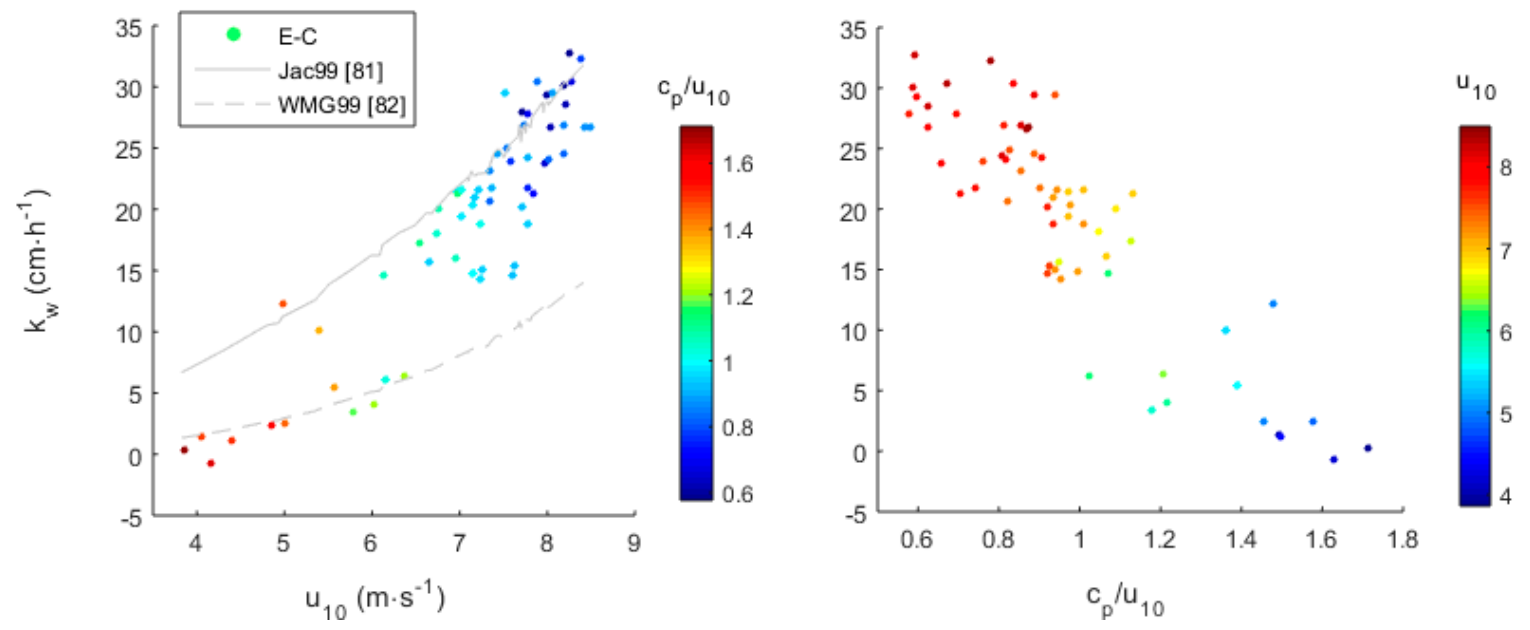

Figure 4. Transfer velocities $\left(\mathrm{k}_{\mathrm{w}}\right)$ estimated for the Baltic experiment from eddy-covariance observations (E-C). The Jac99 (Jacobs et al. [81]) and WMG99 (Wanninkhof and McGillis [82]) are the empirical $\mathrm{u}_{10}$-based parameterizations estimating higher and lower $\mathrm{k}_{\mathrm{w}}$ within this wind range.

The SBL was stable i.e., $0.016<\mathrm{Ri}_{\mathrm{b}}<0.093$. The sea surface was slightly to moderately rough $\left(\mathrm{z}_{0}<0.49 \mathrm{~mm}\right)$. Under these conditions, the $\mathrm{k}_{\mathrm{w}}$ estimated from the E-C measurements were approximate to the $\mathrm{k}_{\mathrm{w}}$ estimated by both empirical $\mathrm{u}_{10}$-based parameterizations and extended physically based algorithms (Figures 4 and 5). The small $k_{w}$ fluctuations estimated by empirical $\mathrm{u}_{10}$-based parameterizations were the sole consequence of changes in water viscosity (as estimated by the $\mathrm{Sc}_{\mathrm{w}}$ ) driven by changes in water temperature. On the other hand, the physically based algorithms, by accounting for the effects of sea state, breaking waves and atmospheric stability, showed a greater 
adaptability to local conditions (Figure 5). As an example, depending on the sea state, the formulations by Woolf [44] or Zhao and Xie [47] estimated $\mathrm{k}_{\mathrm{w}}$ similar to that estimated by the Carini et al. [30] parameterization for the Parker river estuary, or similar to that estimated by the Wanninkhof [29] parameterization for the global ocean. Consequently, the root mean square deviation (RMSD) between the Woolf [44] formulation (henceforth 'W05va') and the E-C transfer velocities was $6.34 \mathrm{~cm} \cdot \mathrm{h}^{-1}$, whereas between the Wan92 and the E-C transfer velocities it was $8.4 \mathrm{~cm} \cdot \mathrm{h}^{-1}$. On relative terms, the physically based algorithm showed $75 \%$ the deviation of the empirical $\mathrm{u}_{10}$-based algorithm. Nevertheless, the physically based algorithms were still unable to accurately fit E-C observations (Figures 4 and 5).
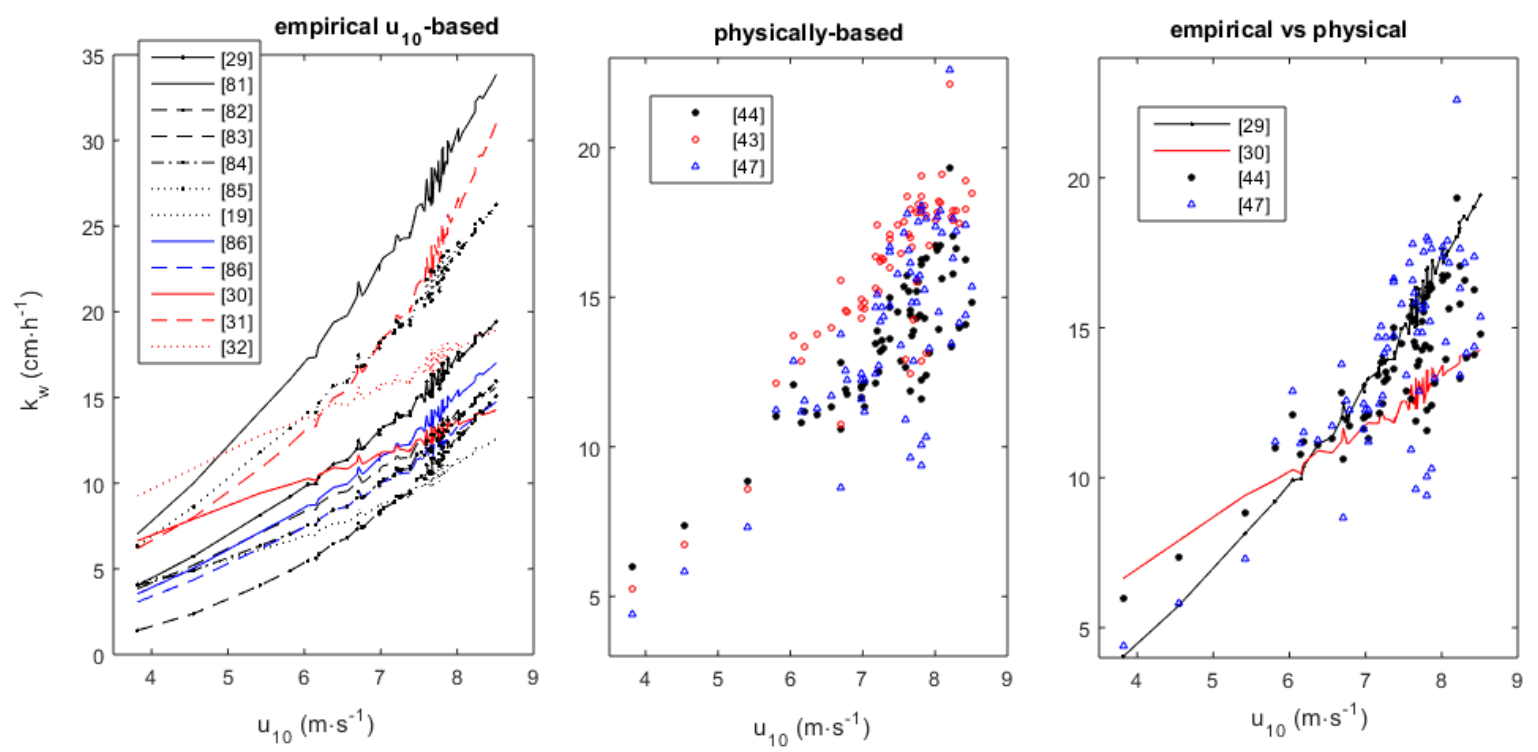

Figure 5. Comparison among transfer velocities $\left(\mathrm{k}_{\mathrm{w}}\right)$ estimated for the Baltic experiment from empirical $\mathrm{u}_{10}$-based parameterizations and from extended physically based formulations. Were tested the empirical $\mathbf{u}_{10}$-based parameterizations by Wanninkhof et al. [19], Wanninkhof [29], Carini et al. [30], Raymond and Cole [31], Borges et al. [32], Jacobs et al. [81], Wanninkhof and McGillis [82], Nightingale et al. [83], McGillis et al. [84], Weiss et al. [85], Ho et al. [86], Were tested the physically-based parameterizations by Zhao et al. [43], Woolf [44] and Zhao and Xie [47] conjugated with the iWLP algorithm specific of the FuGas.

With the optional coupling of the sea state and wind velocity forcings (through the iWLP joint estimate of $z_{0}$ and $u_{*}$ ), the FuGas enables an enhanced representation of local conditions that was demonstrated to be fundamental for the estimation of transfer velocities in fetch-limited situations $[50,55,57]$. This coupling agrees with observations that $\mathrm{k}_{\mathrm{w}}$ scales with the turbulent kinetic energy dissipation at the sea surface $(\varepsilon)$, and that $\varepsilon$ is better reflected by the sea state $[54,56]$. Accordingly, the COARE 3.0 included the wave state in the estimation of the roughness parameters essential for the transfer of mass, heat and momentum [69]. We highlight the fact that the roughness Reynolds number is given by $\mathrm{R}=\mathrm{u} * \mathrm{z}_{0} / \mathrm{v}_{\mathrm{a}}$ i.e., relying precisely on the $\mathrm{u} *$ and $\mathrm{z}_{0}$ that are jointly estimated by the FuGas from the SBL and wave field.

The estimation of $k_{w}$ as wind asymptotically tends to zero is generally considered uninteresting for open ocean formulations, although the equatorial global ocean consistently presents such low winds. The bulk of the empirical $u_{10}$-based parameterizations undervalues the accuracy of the $\mathrm{k}_{\mathrm{w}}$ estimated under the lowest winds and make it asymptotically tending to zero as well. The parameterizations by Mackay and Yeun [87], McGillis et al. [84], Wanninkhof et al. [19] and Johnson [20] propose eliminating this misrepresentation of reality by making $\mathrm{k}_{\mathrm{w}}$ asymptotically tend to a constant. Arguably, the accurate estimation of $\mathrm{k}_{\mathrm{w}}$ under low wind speeds becomes more relevant when studying the coastal ocean and 
inland waters, and extended physically-based algorithms are better suited for the task. The COARE algorithm added a gustiness term stabilizing the $\mathrm{k}_{\mathrm{w}}$ in finite velocities under lighter winds [69]. Clayson et al. [51], on the other hand, replaced the gustiness term by a capillary wave parameterization. The FuGas achieved this through the iterative estimation of the wind log-linear profile (the iWLP: Equations (15) and (16)). Under the lowest winds but as long as there were waves, the smooth flow term in the iWLP imposed finite $u_{*}$, and consequently, finite transfer velocities (Figure 5).

\subsection{Transfer Velocity Estimates from Level 4 Data}

We performed simulations for the European costal ocean to compare between the ESM standard (the 'Wan92') and our extended physically-based alternatives. We show the comparison with the iWLP implemented with the $\mathrm{k}_{\text {wind }}$ formulation by Jähne et al. [66] and the $\mathrm{k}_{\text {bubble formulation by Woolf [44] }}$ using the kinematic viscosity of air (the W05va). Their $\mathrm{k}_{\mathrm{w}}$ estimates diverged mostly under unstable SBL, very rough or very smooth sea-surfaces, or higher friction velocities (Figure 6). The details of the simulations and the differences between $\mathrm{k}_{\mathrm{w}}$ estimates are presented hereafter.
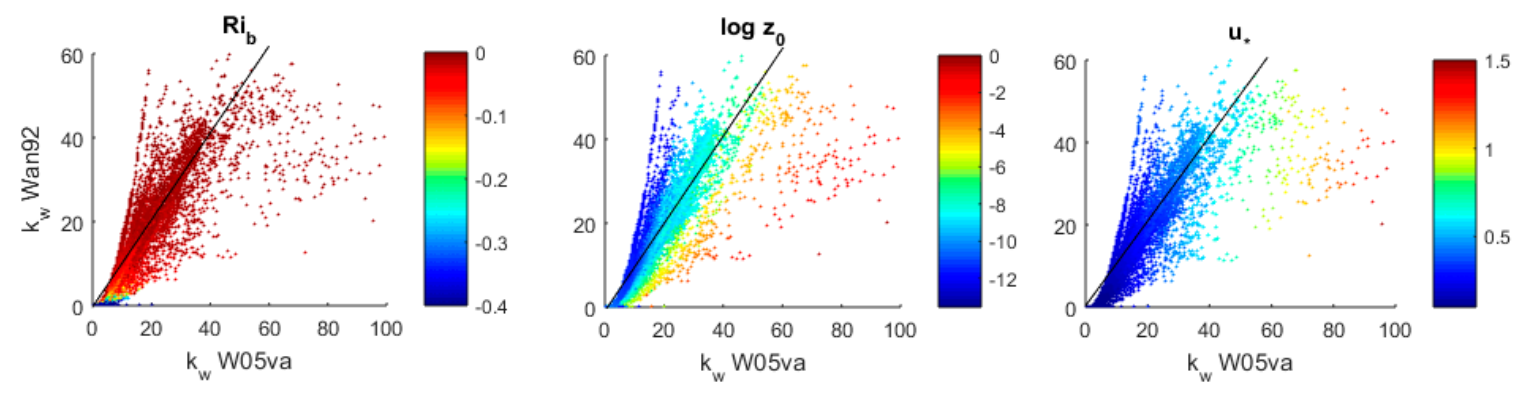

Figure 6. Comparing the formulation by Wanninkhof [29] (Wan92) to the formulation by Woolf [44] (W05va) using modelled data about the European coastal ocean. Differences in the estimates of transfer velocity $\left(\mathrm{k}_{\mathrm{w}}\right)$ as functions of the bulk Richardson number $\left(\mathrm{Ri}_{\mathrm{b}}\right)$, roughness length $\left(\mathrm{z}_{0}\right)$ and friction velocity $\left(u_{*}\right)$. The 1:1 line (in black) represent equal $\mathrm{k}_{\mathrm{w}}$ estimates.

\subsubsection{Atmospheric Stability}

Strong winds occurred along the European shores from the 24-26 May 2014. Besides, the air was unusually cold for the season and colder than the sea surface (Supplementary Video S1). Where the wind blew lighter, the rise of the warmer air heated by the sea surface generated turbulent eddies that enhanced mixing within the SBL and, consequently, also enhanced $\mathrm{u} *$ and $\mathrm{k}_{\mathrm{w}}$. These unstable conditions, identified by $\mathrm{Ri}_{\mathrm{b}}<0$, L tending to -0 and $\psi_{\mathrm{m}}<0$ (Supplementary Video S2), occurred more frequently and intensively nearby land masses and often associated to cooler continental breezes blowing off-shore. Its correct simulation required the estimation of the $\mathrm{Ri}_{\mathrm{b}}, \mathrm{L}$ and $\psi_{\mathrm{m}}$ from the algorithms by Grachev and Fairall [39] and Stull [67] that account for humidity considering saturation at $0 \mathrm{~m}$ heights. The $\mathrm{Ri}_{\mathrm{b}}$ estimates neglecting humidity, following Lee [75], yielded biased estimates of the SBL conditions as a consequence of biased estimates of the virtual potential temperature. Stull [67] (page 9), Grachev and Fairall [39] and Fairall et al. [69] had already highlighted the importance of accounting for humidity.

\subsubsection{Roughness Length}

The sea surface agitation was very heterogeneous, particularly at the coastal ocean where it attained both the highest and the lowest estimated roughness lengths (the $z_{0}$ in Supplementary Video S3). There, the steeper waves, a consequence of shorter fetches, should extract more momentum from the atmosphere under similar $\mathrm{u}_{10}$ conditions $[54-56,58]$. Thus, the rougher coastal ocean surfaces were expected to have relatively more turbulent layers through which gases were transferred at higher rates. The comprehensive formulations simulated this by increasing $\mathrm{u}_{*}$ 
(and consequently $\mathrm{k}_{\text {wind }}$ ) with $\mathrm{z}_{0}$ under similar $\mathrm{u}_{\mathrm{z}}$ i.e., similar winds generate more drag when blowing over rougher sea surfaces. Closer to the shores, and very often within the Mediterranean, lighter wind blew over smoother sea surfaces. Under these conditions, the iWLP estimated much higher $\mathrm{z}_{0}$ than the WLLP (Supplementary Video S4), demonstrating that the smooth flow was a fundamental driver for the $\mathrm{z}_{0}$ under calmer weather. The increase in $\mathrm{z}_{0}$ led to significantly higher $\mathrm{u}_{*}$, often 1.5 times higher and sometimes more, anticipating a significant impact on the local $k_{w i n d}$ estimates. These results demonstrated how the iWLP stabilized the $\mathrm{k}_{\mathrm{w}}$ in finite velocities as wind speed approached zero, and how this becomes a relevant matter when simulating the coastal ocean.

\subsubsection{Transfer Velocities}

In some rare situations the algorithms estimated unreasonably high $\mathrm{k}_{\mathrm{w}}$ despite the $\mathrm{z}_{0}$ bounds imposed in the software. To avoid this bias, a $200 \mathrm{~cm} \cdot \mathrm{h}^{-1}$ ceiling was imposed on all $\mathrm{k}_{\mathrm{w}}$ estimates. The higher transfer velocities were associated to storms, both on the Atlantic side and on the Mediterranean side (Figure 7 and Supplementary Video S5). The root mean square deviation (RMSD) was estimated between the empirical $\mathrm{u}_{10}$-based Wan92 formula and the physically based W05va formula, averaged over time for each location. Results showed that both formulations diverged the most, in absolute terms, under storms and under strong winds near shore (Figure 7). On the other hand, the normalized root mean square deviation (NRMSD) - -i.e., the deviation standardized to the Wan92 prediction-showed that, in relative terms, these formulations diverged the most under low and moderate winds and sea states near shore (Figure 7). The physically-based W05va formulation was also used to compare between the $\mathrm{k}_{\text {wind }}$ and $\mathrm{k}_{\text {bubble }}$ components of the $\mathrm{CO}_{2}$ transfer velocity. The $\mathrm{k}_{\text {bubble }}$ term was always lower than the $\mathrm{k}_{\text {wind }}$ term, and at best $90 \%$ of $\mathrm{k}_{\text {wind }}$ in the fetch-unlimited Atlantic or in the Mediterranean storms (Supplementary Video S5). Over the full domain, the $k_{\text {bubble }}$ term was on average $12 \%$ and on median $15.9 \%$ of the $k_{\text {wind }}$ term. Whatever the greenhouse gas, the differences were negligible between estimating $\mathrm{k}_{\mathrm{w}}$ using the single-layer or the double-layer schemes (Supplementary Video S5). Nevertheless, it is worth noting that the bigger differences were found under Mediterranean storm conditions.
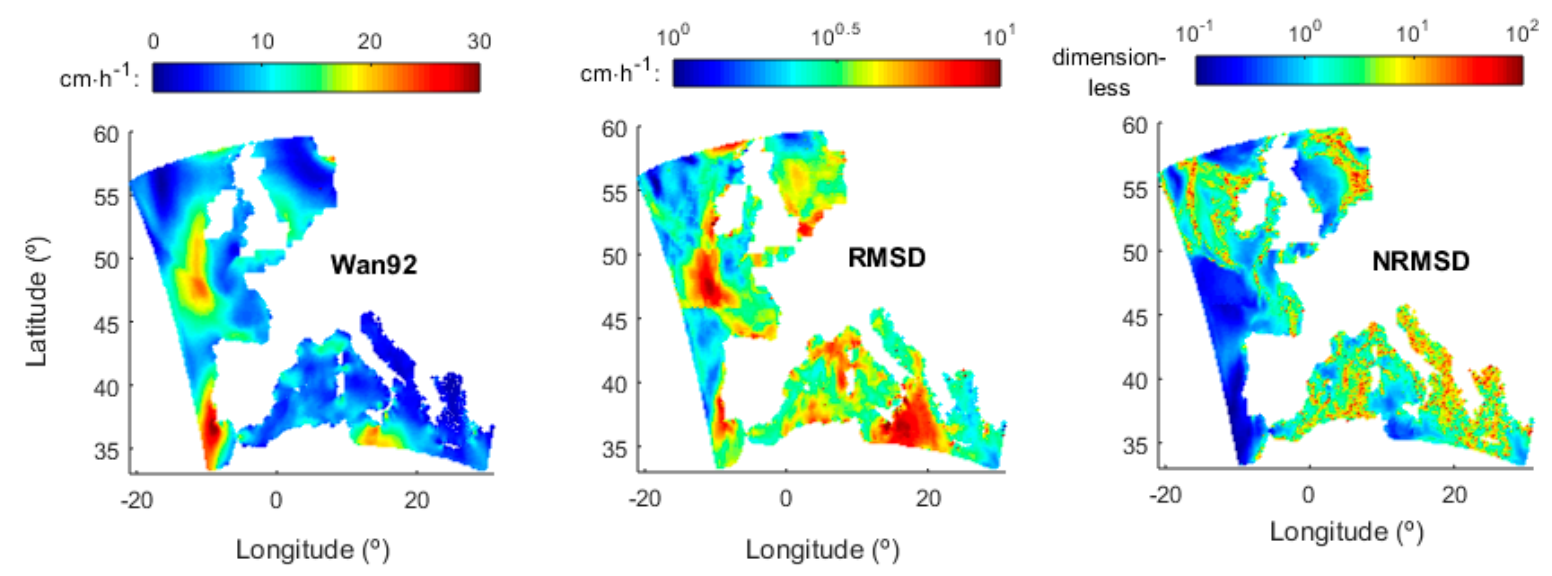

Figure 7. Comparing transfer velocity $\left(\mathrm{k}_{\mathrm{w}}\right)$ algorithms using modelled data: (Wan92) transfer velocity of $\mathrm{CO}_{2}$ estimated from Wanninkhof [29] and averaged over the $66 \mathrm{~h}$; (RMSD) Root mean square deviation between estimating the transfer velocity following Wanninkhof [29] or Woolf [44] conjugated with the iterative wind log-linear profile. (NRMSD) Root mean square deviation normalized to the Wan92 value at each time and location.

\section{Conclusions}

The sea state and atmospheric stability were determinant factors for the gas transfer velocities at the coastal ocean, irrespective of current algorithms still needing calibration and validation. Our findings corroborate recent conclusions that the wave state is fundamental for accurate estimates 
of gas transfer velocities at the fetch-limited coastal ocean [50,57]. Furthermore, our conclusions also agree with Jackson et al. [88] and Shuiqing and Dongliang [49] when inferring about the open ocean. In fact, the COAREG (the gas-dedicated version of the COARE) by Jackson et al. [88] was applied to data from the GasEx cruises on the Northern Atlantic, Equatorial Pacific and Southern Ocean, with their results also suggesting that the sea state and atmospheric stability are important additional factors driving $\mathrm{k}_{\mathrm{w}}$ in particular situations. Our application of the FuGas to the coastal ocean and the Jackson et al. ([88] Figure 11) application of the COAREG to the global ocean even agree in the magnitude of the enhancement of the transfer velocities, when compared to $u_{10}$-based empirical parameterizations. Regarding the coarse resolution of Earth System Models, our FuGas 2.2 application demonstrated that physically-based algorithms diverge even more from empirical $\mathrm{u}_{10}$-based parameterizations when applied over the coastal ocean with finer spatial and temporal resolutions. Jackson et al. [88] also implemented a temporal fine resolution (3 h), having observed a wide discrepancy with the $\mathrm{k}_{\mathrm{w}}$ estimated from monthly means, and concluded that the $\mathrm{k}_{\mathrm{w}}$ estimated from monthly averaged factors is highly biased due to linearization of highly non-linear processes. The chemical enhancement of the transfer velocity is another factor that may become important under the low wind speeds often verified at the coastal ocean. Yet, it still needs to be implemented in the FuGas and tested regarding its functional form, the choice of gases, and the required environmental conditions $[28,89,90]$.

Supplementary Materials: Software, data and table related to this article are available online at http:/ /www. mdpi.com/2073-4433/9/8/310/s1. The latest FuGas version and videos is available at http://www.maretec.org/ en/models/fugas.

Author Contributions: Conceptualization, V.M.N.C.S.V.; Data curation, V.M.N.C.S.V., P.J. and E.C.; Formal analysis, V.M.N.C.S.V.; Funding acquisition, M.M.; Investigation, V.M.N.C.S.V.; Methodology, V.M.N.C.S.V.; Project administration, M.M.; Resources, P.J., E.C. and M.M.; Software, V.M.N.C.S.V.; Supervision, V.M.N.C.S.V.; Validation, V.M.N.C.S.V.; Visualization, V.M.N.C.S.V.; Writing—original draft, V.M.N.C.S.V.; Writing一review and editing, V.M.N.C.S.V., P.J. and M.M.

Funding: This research was funded by ERDF Funds of the Competitiveness Factors Operational ProgrammeCOMPETE and by national funds from the FCT-Foundation for Science and Technology project UID/EEA/50009/2013. The APC was funded by ERDF Funds of the Competitiveness Factors Operational Programme-COMPETE and by national funds from the FCT—Foundation for Science and Technology project UID/EEA/50009/2013.

Acknowledgments: We are thankful to Erik Sahlée for providing the data from Uppsala's University field station in the Baltic, to Heidi Pettersson for providing the data from the Warider Buoy, and to windguru.cz for the support providing the L4 wave data.

Conflicts of Interest: The authors declare no competing financial interests.

\section{References}

1. Takahashi, T.; Sutherland, S.C.; Sweeney, C.; Poisson, A.; Metzl, N.; Tilbrook, B.; Bates, N.; Wanninkhof, R.; Feely, R.A.; Sabine, C.; et al. Global sea-air $\mathrm{CO}_{2}$ flux based on climatological surface ocean $p \mathrm{CO}_{2}$, and seasonal biological and temperature effects. Deep Sea Res. Part II Top. Stud. Oceanogr. 2002, 49, 1601-1622. [CrossRef]

2. Sarmiento, J.L.; Gruber, N. Ocean Biogeochemical Dynamics; Princeton University Press: Princeton, NJ, USA, 2013; pp. 73-100.

3. Gypens, N.; Borges, A.V. Increase in dimethylsulfide (DMS) emissions due to eutrophication of coastal waters offsets their reduction due to ocean acidification. Front. Mar. Sci. 2015, 1. [CrossRef]

4. Menzo, Z.M.; Elliott, S.; Hartin, C.A.; Hoffman, F.M.; Wang, S. Climate change impacts on natural sulfur production: Ocean acidification and community shifts. Atmosphere 2018, 9, 167. [CrossRef]

5. Borges, A.V. Do we have enough pieces of the jigsaw to integrate $\mathrm{CO}_{2}$ fluxes in the coastal ocean? Estuaries 2005, 28, 3-27. [CrossRef]

6. Cole, J.J.; Caraco, N.F. Atmospheric exchange of carbon dioxide in a low-wind oligotrophic lake measured by the addition of $\mathrm{SF}_{6}$. Limnol. Oceanogr. 1998, 43, 647-656. [CrossRef]

7. Cole, J.J.; Caraco, N.F. Carbon in catchments: Connecting terrestrial carbon losses with aquatic metabolism. Mar. Freshw. Res. 2001, 52, 101-110. [CrossRef] 
8. Borges, A.V.; Delille, B.; Frankignoulle, M. Budgeting sinks and sources of $\mathrm{CO}_{2}$ in the coastal ocean: Diversity of ecosystems counts. Geophys. Res. Lett. 2005, 32, L14601. [CrossRef]

9. Rutgersson, A.; Norman, M.; Schneider, B.; Petterson, H.; Sahlée, E. The annual cycle of carbon dioxide and parameters influencing the air-sea carbon exchange in the Baltic Proper. J. Mar. Syst. 2008, 74, 381-394. [CrossRef]

10. Harley, J.F.; Carvalho, L.; Dudley, B.; Heal, K.V.; Rees, R.M.; Skiba, U. Spatial and seasonal fluxes of the greenhouse gases $\mathrm{N}_{2} \mathrm{O}, \mathrm{CO}_{2}$ and $\mathrm{CH}_{4}$ in a UK macrotidal estuary. Estuar. Coast. Shelf Sci. 2015, 153, 62-73. [CrossRef]

11. Lansø, A.S.; Bendtsen, J.; Christensen, J.H.; Sørensen, L.L.; Chen, H.; Meijer, H.A.J.; Geels, C. Sensitivity of the air-sea $\mathrm{CO}_{2}$ exchange in the Baltic Sea and Danish inner waters to atmospheric short-term variability. Biogeosciences 2015, 12, 2753-2772. [CrossRef]

12. Dutta, M.K.; Mukherjee, R.; Jana, T.K.; Mukhopadhyay, S.K. Biogeochemical dynamics of exogenous methane in an estuary associated to a mangrove biosphere; The Sundarbans. NE coast of India. Mar. Chem. 2015, 170, 1-10. [CrossRef]

13. Nevison, C.D.; Weiss, R.F.; Erickson, D.J., III. Global oceanic emissions of nitrous oxide. J. Geophys. Res. 1995, 100, 15809-15820. [CrossRef]

14. Nevison, C.D.; Lueker, T.J.; Weiss, R.F. Quantifying the nitrous oxide source from coastal upwelling. Glob. Biogeochem. Cycles 2004, 18, GB1018. [CrossRef]

15. Barnes, J.; Upstill-Goddard, R.C. $\mathrm{N}_{2} \mathrm{O}$ seasonal distributions and air-sea exchange in UK estuaries: Implications for the tropospheric $\mathrm{N}_{2} \mathrm{O}$ source from European coastal waters. J. Geophys. Res. 2011, 116, G01006. [CrossRef]

16. Smith, S.V.; Hollibaugh, J.T. Coastal metabolism and the oceanic organic carbon balance. Rev. Geophys. 1993, 31, 75-89. [CrossRef]

17. Liss, P.S.; Slater, P.G. Flux of gases across the air-sea interface. Nature 1974, 247, 181-184. [CrossRef]

18. Upstill-Goddard, R.C. Air-sea gas exchange in the coastal zone. Estuar. Coast. Shelf Sci. 2006, 70, 388-404. [CrossRef]

19. Wanninkhof, R.; Asher, W.E.; Ho, D.T.; Sweeney, C.S.; McGillis, W.R. Advances in quantifying air-sea gas exchange and environmental forcing. Annu. Rev. Mar. Sci. 2009, 1, 213-244. [CrossRef] [PubMed]

20. Johnson, M.T. A numerical scheme to calculate temperature and salinity dependent air-water transfer velocities for any gas. Ocean Sci. 2010, 6, 913-932. [CrossRef]

21. Vieira, V.M.N.C.S.; Martins, F.; Silva, J.; Santos, R. Numerical tools to estimate the flux of a gas across the air-water interface and assess the heterogeneity of its forcing functions. Ocean Sci. 2013, 9, 355-375. [CrossRef]

22. Vieira, V.; Sahlée, E.; Jurus, P.; Clementi, E.; Pettersson, H.; Mateus, M. Improving estimates of atmosphere-ocean greenhouse gas fluxes for Earth-System modelling. In ESA SP, Proceedings of the Living Planet Symposium, Prague, Czeck Republic, 9-13 May 2016; European Space Agency: Paris, France, 2016; Volume 740.

23. Weiss, R.F. Carbon dioxide in water and seawater: The solubility of a non-ideal gas. Mar. Chem. 1974, 2, 203-215. [CrossRef]

24. Weiss, R.F.; Price, B.A. Nitrous oxide solubility in water and seawater. Mar. Chem. 1980, 8, 347-359. [CrossRef]

25. Mackay, D.; Shiu, W.Y. A critical review of Henry's law constants of environmental interest. J. Phys. Chem. Ref. Data 1981, 10, 1175-1197. [CrossRef]

26. Copin-Montegut, $\mathrm{C}$. A new formula for the effect of temperature on the partial pressure of $\mathrm{CO}_{2}$ in seawater. Mar. Chem. 1988, 25, 29-37. [CrossRef]

27. Sander, R. Compilation of Henry's law constants (Version 4.0) for water as solvent. Atmos. Chem. Phys. 2015, 15, 4399-4981. [CrossRef]

28. Frew, N.M.; Bock, E.J.; Schimpf, U.; Hara, T.; Haubecker, H.; Edson, J.B.; McGillis, W.R.; Nelson, R.K.; McKenna, S.P.; Uz, B.M.; et al. Air-sea gas transfer: Its dependence on wind stress, small-scale roughness, and surface films. J. Geophys. Res. 2004, 109, C08S17. [CrossRef]

29. Wanninkhof, R. Relationship between wind speed and gas exchange over the ocean. J. Geophys. Res. 1992, 97, 7373-7382. [CrossRef]

30. Carini, S.; Weston, N.; Hopkinson, C.; Tucker, J.; Giblin, A.; Vallino, J. Gas exchange rates in the Parker River estuary, Massachusetts. Biol. Bull. 1996, 191, 333-334. [CrossRef] [PubMed] 
31. Raymond, P.A.; Cole, J.J. Gas exchange in rivers and estuaries: Choosing a gas transfer velocity. Estuaries 2001, 24, 312-317. [CrossRef]

32. Borges, A.V.; Vanderborght, J.P.; Schiettecatte, L.S.; Gazeau, F.; Ferron-Smith, S.; Delille, B.; Frankignoulle, M. Variability of the Gas Transfer Velocity of $\mathrm{CO}_{2}$ in a Macrotidal Estuary (the Scheldt). Estuaries 2004, 27, 593-603. [CrossRef]

33. Soloviev, A.V.; Schlüssel, P. Parameterization of the temperature difference across the cool skin of the ocean and of the air-ocean gas transfer on the basis of modelling surface renewal. J. Phys. Oceanogr. 1994, 24, 1339-1346. [CrossRef]

34. Brunke, M.A.; Zeng, X.; Misra, V.; Beljaars, A. Integration of a prognostic sea surface skin temperature scheme into weather and climate models. J. Geophys. Res. 2008, 113, D21117. [CrossRef]

35. Soloviev, A.; Schlüssel, P. Evolution of cool skin and direct air-sea gas transfer coefficient during daytime. Bound. Layer Meteorol. 1996, 77, 45-68. [CrossRef]

36. Soloviev, A.V.; Lukas, R. Observation of spatial variability of diurnal thermocline and rain-formed halocline in the western Pacific warm pool. J. Phys. Oceanogr. 1996, 26, 2529-2538. [CrossRef]

37. Fairall, C.W.; Bradley, E.F.; Godfrey, J.S.; Wick, G.A.; Edson, J.B.; Young, G.S. Cool-skin and warm-layer effects on sea surface temperature. J. Geophys. Res. 1996, 101, 1295-1308. [CrossRef]

38. Zeng, X.; Beljaars, A. A prognostic scheme of sea surface skin temperature for modelling and data assimilation. Geophys. Res. Lett. 2005, 32, L14605. [CrossRef]

39. Grachev, A.A.; Fairall, C.W. Dependence of the Monin-Obukhov Stability Parameter on the Bulk Richardson Number over the Ocean. J. Appl. Meteorol. 1997, 36, 406-414. [CrossRef]

40. Fairall, C.W.; Hare, J.E.; Edson, J.B.; McGillis, W. Parameterization and micrometerological measurements of air-sea gas transfer. Bound. Layer Meteorol. 2000, 96, 63-105. [CrossRef]

41. Asher, W.E.; Farley, P.J. Phase-Doppler anemometer measurement of bubble concentrations in laboratory-simulated breaking waves. J. Geophys. Res. 1995, 100, 7045-7056. [CrossRef]

42. Woolf, D.K. Bubbles and their role in gas exchange. In The Sea Surface and Global Change; Duce, R.A., Liss, P.S., Eds.; Cambridge University Press: New York, NY, USA, 1997; pp. 173-205.

43. Zhao, D.; Toba, Y.; Suzuki, Y.; Komori, S. Effect of wind waves on air-sea gas exchange: Proposal of an overall $\mathrm{CO}_{2}$ transfer velocity formula as a function of breaking-wave parameter. Tellus B Chem. Phys. Meteorol. 2003, 55, 478-487. [CrossRef]

44. Woolf, D.K. Parameterization of gas transfer velocities and sea state-dependent wave breaking. Tellus $B$ Chem. Phys. Meteorol. 2005, 57, 87-94. [CrossRef]

45. Zhang, W.; Perrie, W.; Vagle, S. Impacts of winter storms on air-sea gas exchange. Geophys. Res. Lett. 2006, 33, L14803. [CrossRef]

46. Jeffery, C.; Robinson, I.; Woolf, D. Tuning a physically-based model of the air-sea gas transfer velocity. Ocean Model. 2010, 31, 28-35. [CrossRef]

47. Zhao, D.; Xie, L. A practical bi-parameter formula of gas transfer velocity depending on wave states. J. Oceanogr. 2010, 66, 663-671. [CrossRef]

48. Goddijn-Murphy, L.; Woolf, D.K.; Callaghan, A.H. Parameterizations and algorithms for oceanic whitecap coverage. J. Phys. Oceanogr. 2011, 41, 742-756. [CrossRef]

49. Shuiqing, L.; Dongliang, Z. Gas transfer velocity in the presence of wave breaking. Tellus B Chem. Phys. Meteorol. 2016, 68, 27034. [CrossRef]

50. Gutiérrez-Loza, L.; Ocampo-Torres, F.J.; Nava, H.G. The effect of breaking waves on $\mathrm{CO}_{2}$ air-sea fluxes in the coastal zone. Bound. Layer Meteorol. 2018. [CrossRef]

51. Clayson, C.A.; Fairall, C.W.; Curry, J.A. Evaluation of turbulent fluxes at the ocean surface using surface renewal theory. J. Geophys. Res. 1996, 101, 28503-28513. [CrossRef]

52. Bock, E.J.; Edson, J.B.; Frew, N.M.; Hara, T.; Haussecker, H.; Jähne, B.; McGillis, W.R.; McKenna, S.P.; Nelson, R.K.; Schimpf, U.; et al. Overview of the CoOP experiment: Physical and chemical measurements parameterizing air-sea heat exchange. In Gas Transfer at Water Surfaces; Donelan, M.A., Drennan, W.M., Saltzman, E.S., Wanninkhof, R., Eds.; AGU: Washington, DC, USA, 2002; pp. 39-44.

53. Zappa, C.J.; Asher, W.E.; Jessup, A.T.; Klinke, J.; Long, S.R. Microbreaking and the enhancement of air-water transfer velocity. J. Geophys. Res. Oceans 2004, 109. [CrossRef]

54. Soloviev, A.; Donelan, M.; Graber, H.; Haus, B.; Schlüssel, P. An approach to estimation of near-surface turbulence and $\mathrm{CO}_{2}$ transfer velocity from remote sensing data. J. Mar. Syst. 2007, 66, 182-194. [CrossRef] 
55. Turney, D.E.; Banerjee, S. Air-water gas transfer and near-surface motions. J. Fluid Mech. 2013, 733, $588-624$. [CrossRef]

56. Wang, B.; Liao, Q.; Fillingham, J.; Bootsma, H.A. On the coefficients of small eddy and surface divergence models for the air-water gas transfer velocity. J. Geophys. Res. Oceans 2015, 120. [CrossRef]

57. Bigdeli, A.; Hara, T.; Loose, B.; Nguyen, A.T. Wave attenuation and gas exchange velocity in marginal sea ice zone. J. Geophys. Res. Oceans 2018, 123. [CrossRef]

58. Frew, N.M.; Nelson, R.K.; McGillis, W.R.; Edson, J.B.; Bock, E.J.; Hara, T. Spatial variations in surface micro-layer surfactants and their role in modulating air-sea exchange. In Gas Transfer at Water Surfaces; Donelan, M.A., Drennan, W.M., Saltzman, E.S., Wanninkhof, R., Eds.; AGU: Washington, DC, USA, 2002; pp. 153-159.

59. McKenna, S.P.; McGillis, W.R. The role of free-surface turbulence and surfactants in air-water gas transfer. Int. J. Heat Mass Transf. 2004, 47, 539-553. [CrossRef]

60. Pereira, R.; Schneider-Zapp, K.; Upstill-Goddard, R.C. Surfactant control of gas transfer velocity along an offshore coastal transect: Results from a laboratory gas exchange tank. Biogeosciences 2016, 13, 3981-3989. [CrossRef]

61. Ho, D.T.; Bliven, L.F.; Wanninkhof, R. The effect of rain on air-water gas exchange. Tellus B Chem. Phys. Meteorol. 1997, 49, 149-158. [CrossRef]

62. Ho, D.T.; Asher, W.E.; Bliven, L.F.; Schlosser, P.; Gordan, E.L. On mechanisms of rain-induced air-water gas exchange. J. Geophys. Res. 2000, 105, 24045-24057. [CrossRef]

63. Frost, T.; Upstill-Goddard, R.C. Meteorological controls of gas exchange at a small English lake. Limnol. Oceanogr. 2002, 47, 1165-1174. [CrossRef]

64. Zappa, C.J.; Ho, D.T.; McGillis, W.R.; Banner, M.L.; Dacey, J.W.H.; Bliven, L.F.; Ma, B.; Nystuen, J. Rain-induced turbulence and air-sea gas transfer. J. Geophys. Res. Oceans 2009, 114. [CrossRef]

65. Zappa, C.J.; Asher, W.E.; Jessup, A.T.; Klinke, J.; Long, S.R. Effect of microscale wave breaking on air-water gas transfer. In Gas Transfer at Water Surfaces; Donelan, M.A., Drennan, W.M., Saltzman, E.S., Wanninkhof, R., Eds.; AGU: Washington, DC, USA, 2002; pp. 23-29.

66. Jähne, B.; Munnich, K.O.; Bosinger, R.; Dutzi, A.; Huber, W.; Libner, P. On the parameters influencing air-water gas exchange. J. Geophys. Res. 1987, 92, 1937-1949. [CrossRef]

67. Stull, R.B. An Introduction to Boundary Layer Meteorology; Kluwer Academic Publishers: Dordrecht, The Netherlands, 1988; pp. 151-195.

68. Taylor, P.K.; Yelland, M.J. The dependence of sea surface roughness on the height and steepness of the waves. J. Phys. Oceanogr. 2001, 31, 572-590. [CrossRef]

69. Fairall, C.W.; Bradley, E.F.; Hare, J.E.; Grachev, A.A.; Edson, J.B. Bulk parameterization of air-sea fluxes: Updates and verification for the COARE algorithm. J. Clim. 2003, 16, 571-591. [CrossRef]

70. Smith, S.D.; Anderson, R.J.; Oost, W.A.; Kraan, C.; Maat, N.; DeCosmo, J.; Katsaros, K.B.; Davidson, K.L.; Bumke, K.; Hasse, L.; et al. Sea surface wind stress and drag coefficients: The HEXOS results. Bound. Layer Meteorol. 1992, 60, 109-142. [CrossRef]

71. Johnson, H.K.; Hoejstrup, J.; Vested, H.J.; Larsen, S.E. Dependence of sea surface roughness on wind waves. J. Phys. Oceanogr. 1998, 28, 1702-1716. [CrossRef]

72. Lange, B.; Johnson, H.K.; Larsen, S.; Hojstrup, J.; Kofoed-Hansen, H.; Yelland, M.J. On detection of a wave age dependency for the sea surface roughness. J. Phys. Oceanogr. 2004, 34, 1441-1458. [CrossRef]

73. Hwang, P. Drag coefficient, dynamic roughness and reference wind speed. J. Oceanogr. 2005, 61, $399-413$. [CrossRef]

74. Pan, Y.; Sha, W.; Zhu, S.; Ge, S. A new parameterization for sea surface aerodynamic roughness. Prog. Nat. Sci. 2008, 18, 1365-1373. [CrossRef]

75. Lee, H.N. Improvement of surface flux calculations in the atmospheric surface layer. J. Appl. Meteorol. 1997, 36, 1416-1423. [CrossRef]

76. Högström, U.; Sahlée, E.; Drennan, W.M.; Kahma, K.K.; Smedman, A.-S.; Johansson, C.; Pettersson, H.; Rutgersson, A.; Tuomi, L.; Zhang, F.; et al. Momentum fluxes and wind gradients in the marine boundary layer-A multi-platform study. Boreal Environ. Res. 2008, 13, 475-502.

77. Donelan, M.A.; Drennan, W.M.; Katsaros, K.B. The air-sea momentum flux in conditions of wind sea and swell. J. Phys. Oceanogr. 1997, 27, 2087-2099. [CrossRef] 
78. Webb, E.K.; Pearman, G.I.; Leuning, R. Correction of flux measurements for density effects due to heat and water vapour transfer. Quart. J. R. Meteorol. Soc. 1980, 106, 85-100. [CrossRef]

79. Clementi, E.; Oddo, P.; Korres, G.; Drudi, M.; Pinardi, N. Coupled wave-ocean modelling system in the Mediterranean Sea. In Proceedings of the 13th International Workshop on Wave Hindcasting, Banff, AB, Canada, 27 October-1 November 2013.

80. EPA United States Environmental Protection Agency. Climate Change Indicators in the United States-Atmospheric Concentrations of Greenhouse Gases. Available online: https://www.epa.gov/ climate-indicators / climate-change-indicators-atmospheric-concentrations-greenhouse-gases (accessed on 29 April 2018).

81. Jacobs, C.M.J.; Kohsiek, W.; Oost, W.A. Air-sea fluxes and transfer velocity of $\mathrm{CO}_{2}$ over the North Sea: Results from ASGAMAGE. Tellus B Chem. Phys. Meteorol. 1999, 51, 629-641. [CrossRef]

82. Wanninkhof, R.; McGillis, W.R. A cubic relationship between air-sea $\mathrm{CO}_{2}$ exchange and wind speed. Geophys. Res. Lett. 1999, 26, 1889-1892. [CrossRef]

83. Nightingale, P.D.; Malin, G.; Law, C.S.; Watson, A.J.; Liss, P.S.; Liddicoat, M.I.; Boutin, J.; Upstill-Goddard, R.C. In Situ evaluation of air-sea gas exchange parameterizations using novel conservative and volatile tracers. Glob. Biogeochem. Cycles 2000, 14, 373-387. [CrossRef]

84. McGillis, W.R.; Edson, J.B.; Ware, J.D.; Dacey, J.W.H.; Hare, J.E.; Fairall, C.W.; Wanninkhof, R. Carbon dioxide flux techniques performed during GasEx-98. Mar. Chem. 2001, 75, 267-280. [CrossRef]

85. Weiss, A.; Kuss, J.; Peters, G.; Schneider, B. Evaluating transfer velocity-wind speed relationship using a long-term series of direct eddy correlation $\mathrm{CO}_{2}$ flux measurements. J. Mar. Syst. 2007, 66, 130-139. [CrossRef]

86. Ho, D.T.; Law, C.S.; Smith, M.J.; Schlosser, P.; Harvey, M.; Hill, P. Measurements of air-sea gas exchange at high wind speeds in the Southern Ocean: Implications for global parameterizations. Geophys. Res. Lett. 2006, 33, L16611. [CrossRef]

87. Mackay, D.; Yeun, A.T.K. Mass transfer coefficient correlations for volatilization of organic solutes from water. Environ. Sci. Technol. 1983, 17, 211-217. [CrossRef] [PubMed]

88. Jackson, D.L.; Wick, G.A.; Hare, J.E. A comparison of satellite-derived carbon dioxide transfer velocities from a physically based model with GasEx cruise observations. J. Geophys. Res. 2012, 117, G00F13. [CrossRef]

89. Wanninkhof, R.; Knox, M. Chemical enhancement of $\mathrm{CO}_{2}$ exchange in natural waters. Limnol. Oceanogr. 1996, 41, 689-697. [CrossRef]

90. Bade, D.L.; Cole, J.J. Impact of chemically enhanced diffusion on dissolved inorganic carbon stable isotopes in a fertilized lake. J. Geophys. Res. 2006, 111, C01014. [CrossRef] 